\title{
Inhibitory Effects of Hybrid Liposomes on the Growth of Non-small Cell Lung Carcinoma Cells and Anti-invasive Activity by Ceramide Generation without any Drugs
}

\author{
Hideaki Ichihara, Yuji Komizu, Ryuichi Ueoka and Yoko Matsumoto* \\ Division of Applied Life Science, Graduate School of Engineering, Sojo University, Ikeda, Nishi-ku, Kumamoto, Japan.
}

"Corresponding author: Yoko Matsumoto, Division of Applied Life Science, Graduate School of Engineering, Sojo University, 4-22-1 Ikeda, Nishi-ku, Kumamoto 860-0082, Japan, Tel +81 96326 3965; Fax+81 96323 1311; E-mail: matumoto@life.sojo-u.ac.jp

Received date: Jun 08, 2015; Accepted date: July 03, 2015; Published date: July 06, 2015

Copyright: $\bigcirc 2015$ Ichihara $\mathrm{H}$, et al. This is an open-access article distributed under the terms of the Creative Commons Attribution License, which permits unrestricted use, distribution, and reproduction in any medium, provided the original author and source are credited.

Abstract
Ceramide generation and invasive inhibition by hybrid liposomes $(\mathrm{HL})$ composed of 90 mol\% L-a-dimyristoyl-
phosphatidylcholine (DMPC) and 10 mol\% polyoxyethylene $(23)$ dodecyl ether $\left(\mathrm{C}_{12}(\mathrm{EO})_{23}\right)$ were examined for
human lung cancer (A549) cells in vitro. Ceramide generation for A549 cells treated with $\mathrm{HL}$ was observed through
the activation of neutral sphingomyelinase. These was a reduction in sphingomyelin in $\mathrm{A} 549$ cells after treatment
with HL. The anti-invasive effects of $\mathrm{HL}$ for A549 cells were obtained through the inhibition of MT1MMP/MMP14.
Inhibitory effects of HL on the migration of A549 cells was obtained using scratch assay.

Keywords: Hybrid liposome; Lung cancer; Ceramide; Anti-invasive

\section{Abbreviations}

$\mathrm{C}_{12}(\mathrm{EO})_{23}$ : Polyoxyethylene(23) Dodecyl Ether; DMPC: L- $\alpha-$ Imyristoylphosphatidylcholine; HL: Hybrid Liposomes Composed of DMPC and C12(EO)23; N-SMase: Neutral Sphingomyelinase; NSCLC: Non-small Cell Lung Carcinoma

\section{Introduction}

Non-small cell lung carcinoma (NSCLC) is the most common form of lung cancer, which accounts for up to $85 \%$ of deaths $[1,2]$. Metastasis in NSCLC is the major cause of mortality among patients $[3,4]$. Lymph node metastasis and invasion to neighbouring organs are as the most important indicators of poor prognosis [4,5]. In the recent years, several potential oncogenic drivers have been identified in patients with NSCLC, including epidermal growth factor receptor (EGFR), B-Raf (BRAF), Kirsten rat sarcoma 2 viral oncogene homolog (KRAS), mesenchymal epithelial transition factor (MET), human epidermal growth factor receptor 2 (HER2), and anaplastic lymphoma kinase gene (ALK) [6-9]. The inhibitors for these genes such as the gefitinib and crizotinib are used in the treatment for the patients with NSCLC $[8,10,11]$. However, these drugs for NSCLC have adverse events $[10,11]$. Therefore, novel treatment strategies directed against NSCLC are needed.

We have produced hybrid liposomes (HL) composed of vesicular and micellar molecules without organic solvent [12]. The physical properties of HL such as shape, size, membrane fluidity of phase transition can be controlled by changing the constituents and compositional ratio. Remarkably high inhibitory effects of HL composed of DMPC and polyoxyethylene(n) dodecyl ethers $\left(\mathrm{C}_{12}(\mathrm{EO})_{\mathrm{n}}\right)$ on the growth of tumor cells in vitro [13-17], in vivo [17-21], and clinical application [22-24] have been obtained without drugs. We have reported HL induced apoptosis in various cancer cells including NSCLC (A549, H460, H23 and H520) cells [25].
Furthermore, HL induced cell cycle arrest at $G_{0} / G_{1}$ phase in NSCLC cells through the inhibition of Akt signaling [26]. In addition, it has been reported that HL treatment altered the amounts of sphingomyelin and ceramide [27]. Ceramide is a sphingolipid-derived second messenger in cell the membrane in response to inflammation and stress [28]. It is related to cellular differentiation, proliferation and apoptosis pathways $[28,29]$.

In this study, we investigated ceramide generation and invasive inhibition by HL composed of L-a-dimyristoylphosphatidylcholine (DMPC) and polyoxyethylene(23) dodecyl ether $\left(\mathrm{C}_{12}(\mathrm{EO})_{23}\right)$ for nonsmall cell lung carcinoma cells.

\section{Experimental Section}

\section{Preparation of hybrid liposomes}

Hybrid liposomes (HL) were prepared by sonication of a mixture containing $90 \mathrm{~mol} \% \mathrm{~L}$ - $\alpha$-dimyristoylphosphatidylcholine (DMPC, NOF, Tokyo, Japan) and $10 \mathrm{~mol} \%$ polyoxyethylene(23) dodecylether $\left(\mathrm{C}_{12}(\mathrm{EO})_{25}\right.$, Nikko Chemicals, Tokyo, Japan, $)$ in $5 \%$ glucose solution using bath type sonicater (VS-N300, VELVO-CLEAR, Tokyo, Japan) at $45^{\circ} \mathrm{C}$ with $300 \mathrm{~W}$. The sample solutions were filtered using a membrane filter (Advantec, Tokyo, Japan) with $0.20 \mu \mathrm{m}$ pore size and stored at room temperature $\left(25^{\circ} \mathrm{C}\right)$. The DMPC liposomes were prepared in the same manner as described above.

\section{Dynamic light scattering measurements}

The diameter of HL was measured using an electrophoretic light scattering spectrophotometer (ELS-Z0, Otsuka Electronics, Osaka, Japan). The diameter (dhy) was calculated using the Stokes-Einstein formula (Equation 1), where $\kappa$ is the Boltzmann constant, $\mathrm{T}$ is the absolute temperature, $\eta$ is the viscosity and $D$ is the diffusion coefficient:

$$
\text { dhy }=\kappa \mathrm{T} / 3 \pi \eta \mathrm{D}(\text { Equation } 1)
$$


Citation: Ichihara H, Komizu Y, Ueoka R, Matsumoto Y (2015) Inhibitory Effects of Hybrid Liposomes on the Growth of Non-small Cell Lung Carcinoma Cells and Anti-invasive Activity by Ceramide Generation without any Drugs. J Carcinog Mutagen 6: 230. doi: $10.4172 / 2157-2518.1000230$

Page 2 of 5

\section{Cell culture}

Human non-small cell lung carcinoma (A549) cell lines were obtained from Riken Cell Banc (Ibaraki, Japan). A549 cells were cultured in D-MEM medium (Life Technologies, Carlsbad, CA, USA) supplement with penicillin (100 unit/ml), streptomycin $(50 \mu \mathrm{g} / \mathrm{ml})$ and $10 \%$ fetal bovine serum (FBS, HyClone Laboratories Inc., UT, USA) in the atmosphere of $5 \% \mathrm{CO}_{2}$ and humidified atmosphere at $37^{\circ} \mathrm{C}$.

\section{Ceramide assay by confocal laser microscope}

Cells were seeded at a density of $4.0 \times 10^{3}$ cells pre well in 8-well chamber slides (Lab-Tek II, Thermo Fisher Scientific, MA, USA) and incubated for 24 hours. Then, HL was added $(200$ and $300 \mu \mathrm{M})$ and the plates were incubated for 3 hours. The cells were washed and directly fixed with $10 \%$ formaldehyde for $30 \mathrm{~min}$ in the wells. Cells were washed and permeabilized with ice-cold $100 \%$ methanol for 10 min at $-20^{\circ} \mathrm{C}$. Cells were blocked with $5 \%$ goat serum in PBS(-). After that, cells were washed twice and incubated with anti-ceramide mouse IgM monoclonal antibody (diluted 1:250, Enzo Life Sciences, NY, USA) at $4^{\circ} \mathrm{C}$ for 18 hours and Alexa Fluor $488^{\circ}$ Goat Anti-Mouse IgG antibody (diluted 1:200, Invitrogen, CA, USA) in humidified box at room temperature for 1 hours. Finally, the cells were counterstained with TO-PRO-3 (Invitrogen, CA, USA). The stained cells were observed using a confocal laser microscope (TCS-SP; Leica Microsystems, Wetzlar Germany) with a $488 \mathrm{~nm}$ Ar laser. The Alexa Fluor $488^{\circ}$ fluorescein signals were detected at 515-565 $\mathrm{nm}$ and the TO-PRO-3 signals were detected at $649-740 \mathrm{~nm}$.

\section{Ceramide assay with sphingomyelinase by flow cytometry}

Ceramide expression was detected by immunocytochemistry using a flow cytometer. Cells were seeded at a density of $1.0 \times 10^{5}$ cells per well in dishes and incubated for 24 hours. Cells were pretreated with GW4869 (neutral sphingomyelinase (nSMase) inhibitor, $3 \mu \mathrm{M}$, Merck Millipore, MA, USA) for $30 \mathrm{~min}$ [30,31]. Cells were treated with HL (300 and $500 \mu \mathrm{M}$ ) for 3 hours. Briefly, cells were washed with PBS (-), trypsinized, centrifuged and fixed with $10 \%$ formaldehyde for $30 \mathrm{~min}$ in the wells. Cells were washed and permeabilized with 100\% methanol for $5 \mathrm{~min}$ on ice. After that, cells were washed twice and incubated with anti-ceramide mouse IgM monoclonal antibody (diluted 1:200) at room temperature for $30 \mathrm{~min}$ and Alexa Fluor $488^{\circ}$ Goat Anti-Mouse IgG antibody (diluted 1:200) in humidified box at $4^{\circ} \mathrm{C}$ for $1 \mathrm{~h}$. Cells were washed and measured by a flow cytometer.

\section{Sphingomyelin assay}

Sphingomyelin in cell were detected using sphingomyelin quantification colorimetric assay kit (Bio Vision, CA, USA) according to the manufacturer's directions. Cells were seeded at a density of $1.0 \times$ $10^{5}$ cells per well in dishes and incubated for 24 hours. Cells were treated with HL $(300 \mu \mathrm{M})$ for 24 hours. Cells were washed with PBS(-), trypsinized and centrifuged. Then, collected cells were homogenized for three times using ultrasonic cell crushing apparatus (XL2020, Misonix ASTRASON, MISONIX INC., NY, USA). Homogenate was centrifuged and heated at $70^{\circ} \mathrm{C}$. Membrane lipids were extracted from heated homogenate. After that, sphingomyelin in extract was stained with highly specific probe (OxiRed Probe, Bio Vision, CA, USA) and measured at absorbance $(570 \mathrm{~nm})$ in a microplate reader (Molecular Devices, CA, USA).

\section{Invasion assay in vitro}

In vitro cancer cell invasion was assessed using a Biocoat ${ }^{\text {ma }}$ Matrigel invasion chamber (BD Biosciences, NJ, USA) with cell culture inserts containing an $8 \mu \mathrm{m}$ pore size membrane with a thin layer of Matrigel basement membrane matrix. Briefly, $450 \mu \mathrm{l}$ of A549 cells $\left(4.0 \times 10^{4}\right.$ cells $/ \mathrm{ml}$ ) were re-suspended in a serum-free medium containing either $5 \%$ glucose solution (control) or HL $(100,200,300 \mu \mathrm{M})$ which was added to the cell culture insert of a Biocoat ${ }^{\mathrm{mm}}$ Matrigel $^{\mathrm{mt}}$ invasion chamber. Then, $0.7 \mathrm{ml}$ of medium supplemented with $10 \%$ FBS was added in the outer chamber as a chemoattractant. The cells were then incubated at $37^{\circ} \mathrm{C}$ in humidified $5 \% \mathrm{CO}_{2}$ conditions for $24 \mathrm{~h}$. To quantitative tumor cell invasion, non-invading cells were removed from the upper surface of the membrane by scrubbing gently with a cotton-tipped swab. The cells on the lower surface of the membrane were fixed with ethanol and stained with crystal violet. The cells were photographed using a light microscope (ECLIPSE TS100, Nikon, Tokyo, Japan). Microscope fields of the lower surface of the membrane were counted for numbers of cells that had invaded through the Matrigel layer and the membrane. The results were expressed as numbers of invaded cells per microscope field.

\section{Assessment of MT1-MMP (MMP-14) by flow cytometry}

A549 cells were seeded at a density of $1.0 \times 10^{5}$ cells per well in dishes and incubated for 24 hours. Cells were treated with HL (300 and $500 \mu \mathrm{M})$ for 3 and 24 hours. Cells were washed with PBS (-), trypsinized, centrifuged at $1500 \mathrm{rpm} \times 5 \mathrm{~min}$ and fixed with $10 \%$ formaldehyde for $30 \mathrm{~min}$ in the wells. Cells were permeabilized with cold methyl alcohol in PBS (-) for 30 min on ice. After that, cells were washed twice and incubated with anti-MMP14 rabbit monoclonal antibody (Abcam plc, Cambridge, UK) $(5 \mu \mathrm{g} / \mathrm{ml})$ at room temperature for $30 \mathrm{~min}$ and Alexa Fluor $488^{\circ}$ Goat Anti-Mouse IgG $(10 \mu \mathrm{g} / \mathrm{ml})$ antibody in humidified box at $4^{\circ} \mathrm{C}$ for $1 \mathrm{~h}$. Cells were washed and measured by a flow cytometer.

\section{Scratch wound assay in vitro}

A549 motility was assessed using a scratch wound assay. The cells were seeded into tissue culture dishes at a concentration of $2.5 \times 10^{5}$ cells $/ \mathrm{ml}$ and cultured in medium containing $10 \%$ FBS to nearly confluent cell monolayers, which were then carefully wounded using a $200 \mu \mathrm{l}$ sterile pipette tip, and any cellular debris was removed by washing with PBS(-). The wounded monolayers were then incubated in medium containing $10 \%$ FBS and treated with or without $100 \mu \mathrm{M}$ HL. After $19 \mathrm{~h}$, the cells were photographed under a light microscope (EVOS fl, Life Technologies, CA. USA). The migration areas were estimated using image analysis software ImageJ (Version 1.46r, National Institutes of Health, Bethesda, MD, USA).

\section{Statistical analysis}

Results are presented as mean \pm S.D. Data were statistically analyzed using Student's t-test. A p value of less than 0.05 was considered to represent a statistically significant difference.

\section{Results and Discussions}

\section{Physical properties of HL}

We examined the morphology of HL composed of $90 \mathrm{~mol} \%$ DMPC and $10 \mathrm{~mol} \% \mathrm{C}_{12}(\mathrm{EO})_{23}$ on the basis of dynamic light scattering 
Citation: Ichihara H, Komizu Y, Ueoka R, Matsumoto Y (2015) Inhibitory Effects of Hybrid Liposomes on the Growth of Non-small Cell Lung Carcinoma Cells and Anti-invasive Activity by Ceramide Generation without any Drugs. J Carcinog Mutagen 6: 230. doi: $10.4172 / 2157-2518.1000230$

Page 3 of 5

measurements. The time course of the hydrodynamic diameter (dhy) change for HL was examined using an electrophoretic light scattering spectrophotometer. The mean dhy of HL stored at room temperature $\left(25^{\circ} \mathrm{C}\right)$ was under $100 \mathrm{~nm}$ with a single and narrow distribution and remained stable for more than one month. In contrast, DMPC liposomes were unstable and precipitated after 14 days. HL were kept at room temperature due to the convenience of stocking for a long term period prior to clinical application. It is worthwhile to note that HL being under $100 \mathrm{~nm}$ in diameter could avoid the reticular endotherial system (RES) [32] and thus should be appropriate for intravenous administration in vivo and clinical applications.

\section{Effects of HL on ceramide generation}

We examined the effects of HL on ceramide generation in A549 cells on the basis of immunocytochemistry using a confocal laser microscope. The results are shown in Figure 1. Increase ceramide generation was observed in A549 cells after the treatment with HL in a dose-dependent manner. We have already reported that HL treatment altered the amounts of ceramide [27]. These results strongly suggest HL induced ceramide generation in A549 cells.

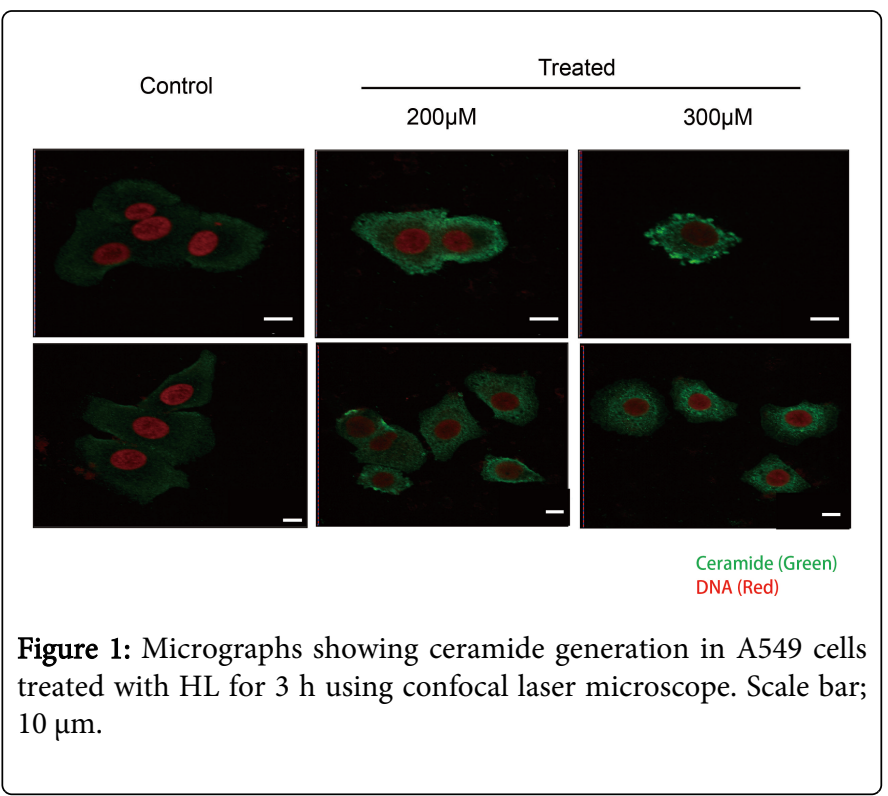

\section{Effects of $\mathrm{HL}$ on sphingomyelinase in vitro}

Ceramide can also be generated in the plasma membrane by the action of SMases [29]. We examined the effects of HL on the activating of neutral sphingomyelinase (N-SMase) using GW4869 nSMase inhibitor by flow cytometric analysis in vitro. The results are shown in Figure 2. Inhibition of ceramide generation in A549 cells treated with HL with GW4869 N-SMase inhibitor $(\mathrm{p}<0.05)$ was obtained, although an increase of the ceramide in A549 cells after treatment with HL was observed in a dose-dependent manner. These results indicate that ceramide generation by HL in A549 cells was involved in the activation of N-SMase.

\section{Effects of HL on sphingomyelin}

Ceramide are synthesized from sphingomyelin in the plasma membrane by activation of $\mathrm{N}$-SMases [29]. We examined the amount of sphingomyelin in A549 cells using a sphingomyelin quantification colorimetric assay kit in vitro. The results are shown in Figure 3. The amount of sphingomyelin in A549 cells after the treatment with HL decreased $(\mathrm{p}<0.05)$. This result suggests that HL could synthesize the ceramide from sphingomyelin by activation of N-SMases in vitro. Furthermore, we are now investigating mechanism of ceramide generation by HL in detail.

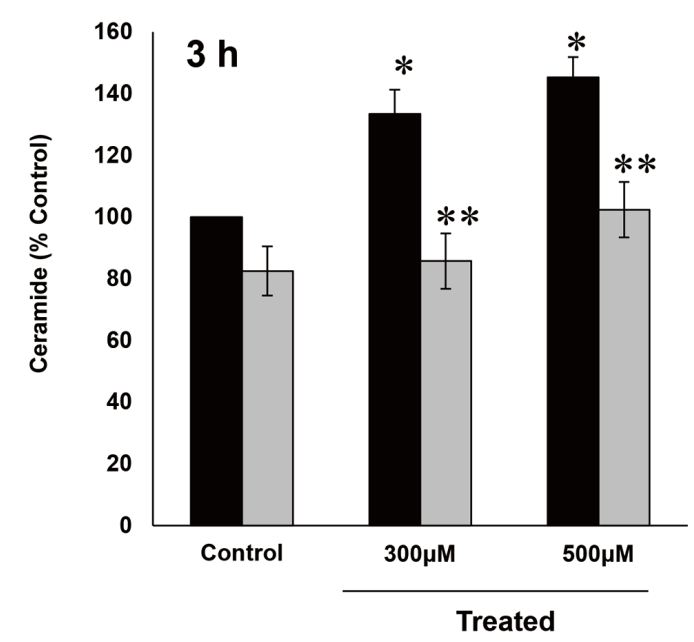

口: HL

a: GW4869 (inhibitor of N-SMase (neutral sphingomyelinase))

Figure 2: Relative content of ceramide in A549 cells treated with HL for $3 \mathrm{~h}$ with and without neutral sphingomyelinase inhibitor (GW4869). Data represent the mean $(n=4-7) \pm$ S.E. * Significant difference $(\mathrm{p}<0.05)$ from Control calculated using by Student's $t$ test. ${ }^{* *}$ Significantly different $(\mathrm{p}<0.05)$ from HL with GW4869

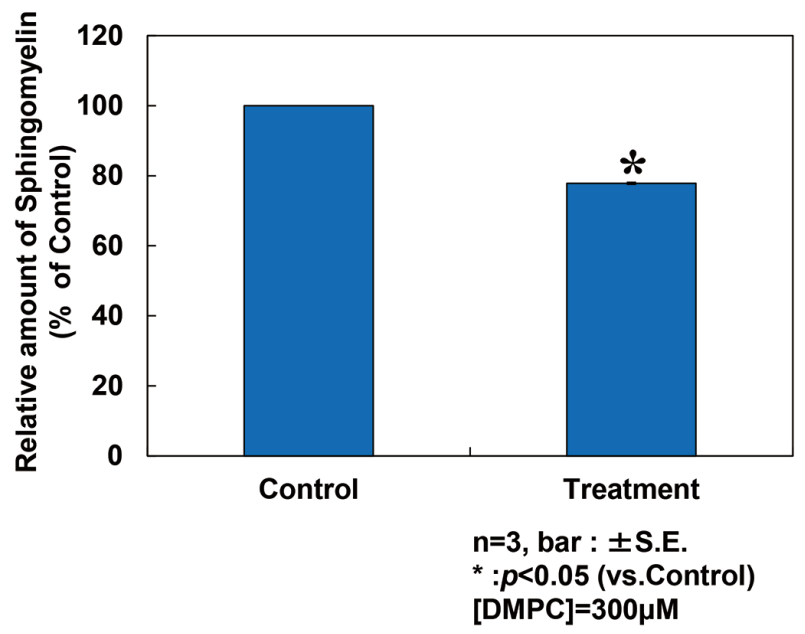

Figure 3: Relative amount of sphingomyelin in A549 cells treated with HL for $24 \mathrm{~h}$. Data represent the mean $(n=3) \pm$ S.E. ${ }^{*}$ Significant difference $(\mathrm{p}<0.05)$ from Control calculated using by Student's ttest. HL, $[\mathrm{DMPC}]=300 \mu \mathrm{M},\left[\mathrm{C}_{12}(\mathrm{EO})_{23}\right]=33 \mu \mathrm{M}$ 
Citation: Ichihara H, Komizu Y, Ueoka R, Matsumoto Y (2015) Inhibitory Effects of Hybrid Liposomes on the Growth of Non-small Cell Lung Carcinoma Cells and Anti-invasive Activity by Ceramide Generation without any Drugs. J Carcinog Mutagen 6: 230. doi: $10.4172 / 2157-2518.1000230$

Page 4 of 5

\section{Inhibitory effects of HL on invasion}

Tumor cell invasion is an important early step in the process of tumor metastasis. In vitro tumor cell invasion was performed on the invasion assay using a Matrigel invasion chamber. The results are shown in Figure 4. The invasion rate of A549 cells treated with HL significantly decreased in a dose-dependent manner (Figures $4 \mathrm{~A}$ and $4 \mathrm{~B})$. Interestingly, the anti-invasive effects of $\mathrm{HL}$ were observed at low concentrations $(100,150$ and $200 \mu \mathrm{M})$ without growth-inhibition under $\mathrm{IC}_{50}$ values $(238 \mu \mathrm{M})$ [25].

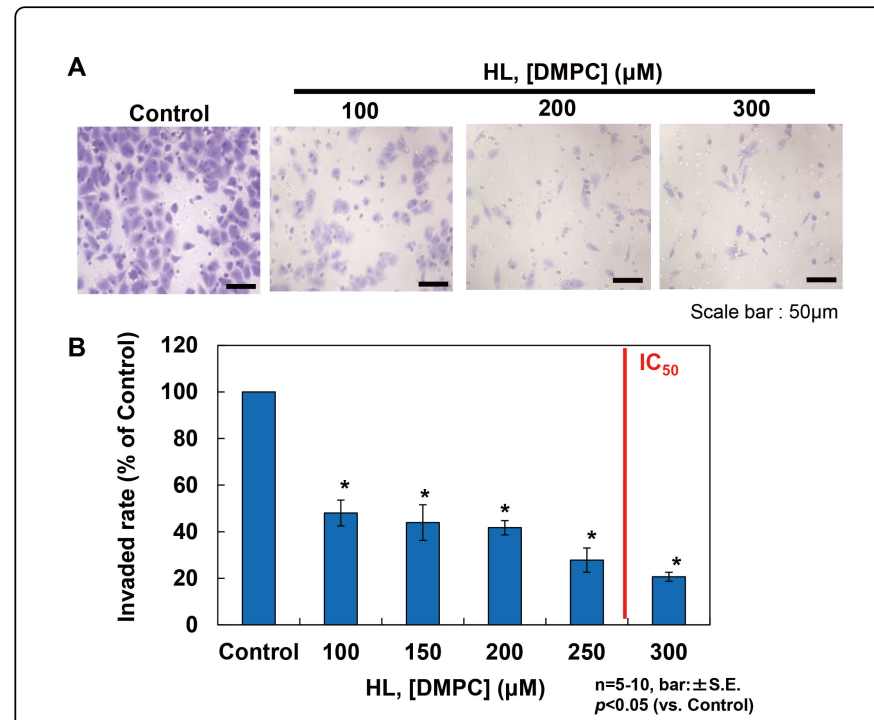

Figure 4: Inhibitory effects of HL on invasion of A549 cells In vitro invasion assay using Matrigel invasion chamber. (A) Representative images for invaded cells in the presence or absence of HL. The cells were stained with crystal violet. Scale bar; $50 \mu \mathrm{m}$. (B) Quantification of invaded cells in (Figure 2A). The data shown are the mean \pm SE $(n=5)$ from three independent experiments. Significant difference $\left({ }^{*} \mathrm{p}<0.001\right)$ compared with control.

We examined the effects of HL on the activation of membrane type 1 metalloprotease (MT1-MMP/MMP14) in A549 cells on the basis of immunocytochemistry using a flow cytometer. MT1-MMP/MMP14 is a transmembrane metalloprotease that involve in pericellular proteolysis and invasion and indirectly by activating pro-MMP2. The results are shown in Figure 5. The relative protein expression of MT1MMP/MMP14 in A549 cells treated with HL decreased in time- and dose-dependent manner. We are now investigating inhibitory effects of HL for activation of MMPs such as MT1-MMP, MMP-2 and MMP-9 in A549 cells in vitro. These results suggest that HL could inhibit the inversion of A549 cells in vitro.

\section{Inhibitory effects of HL on migration}

To examine whether the anti-invasive effect of HL is associated with its suppression of the cell motility, the effect of HL on the migration capability of cells was analyzed by using scratch wound assay. The confluent monolayer of A549 cells was scratch-wounded with $200 \mu \mathrm{l}$ sterile pipette tips and post-incubated for a further $19 \mathrm{~h}$ in the absence (control) or presence of HL. The results are shown in Figure 6. HL inhibited the migration of A549 compared with control cells. The antimigrate effects of HL were observed at low concentrations $(100 \mu \mathrm{M})$ without growth-inhibition under $\mathrm{IC}_{50}$ values $(238 \mu \mathrm{M})$ [25] and within the doubling time $(22 \mathrm{~h})$ of A549 cells in ATCC protocol. Ceramide activates protein phosphatase $2 \mathrm{~A}$ (PP2A) [33], which is known to negatively regulate the phosphorylated-Akt (p-Akt) [34] and then Akt regulates actin organization and cell motility [35]. It has been reported that treatment of A549 cells with HL inhibited phosphorylation of Akt on the basis of immunocytochemistry using flow cytometer, and downregulation of p-Akt by HL could be related to blocking the actin cytoskeleton dynamics such as filopodia formation [26]. Thus, these results suggest that HL could induce ceramide generation, downregulate $\mathrm{p}$-Akt and block the actin cytoskeleton, which inhibit migration of A549 cells.
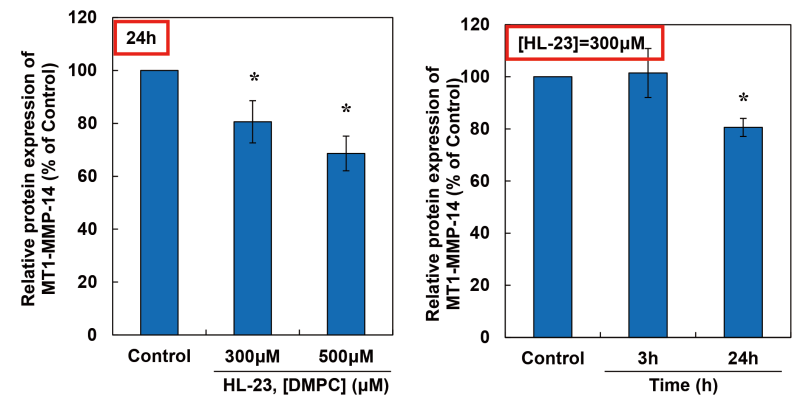

Figure 5: Relative expression values of MT1-MMP (MMP-14) in A549 cells treated with HL-23 (300 and $500 \mu \mathrm{M})$ for $24 \mathrm{~h}$ (A). Relative expression values of MT1-MMP (MMP-14) in A549 cells treated with HL-23 $(300 \mu \mathrm{M})$ for 3 and $24 \mathrm{~h}(\mathrm{~B})$. Data represent the mean $(n=3-4) \pm$ S.E. * Significant difference $(\mathrm{p}<0.05)$ from Control calculated using by Student's t-test.
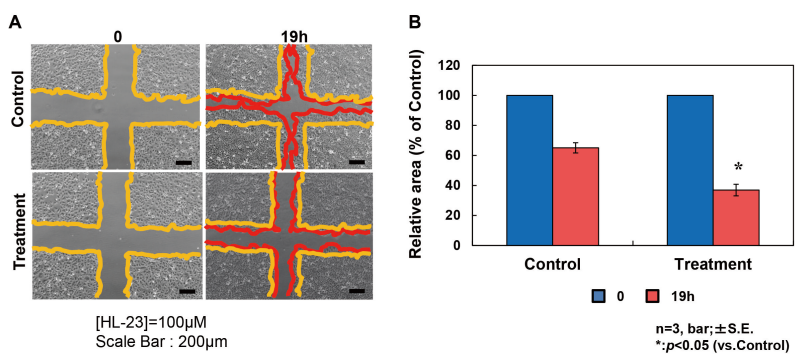

Figure 6: Inhibitory effects of HL on the migration of A549 cells using scratch wound assay. (A)Yellow lines indicate initial wound area; red lines demarcate migrating cells. Scale bar; $200 \mu \mathrm{m}$. (B) Relative area of migrated A549 cells in the presence or absence of HL for $19 \mathrm{~h}$. Data represent the mean $(n=3) \pm$ S.E. * Significant difference from $(\mathrm{p}<0.05)$ from Control calculated using by Student's t-test. HL, $[\mathrm{DMPC}]=100 \mu \mathrm{M},\left[\mathrm{C}_{12}(\mathrm{EO})_{23}\right]=11 \mu \mathrm{M}$.

\section{Conclusion}

We clearly demonstrated the ceramide generation and invasive inhibition by HL on A549 cells. The noteworthy aspects in this study are as follows: (a) Ceramide generation for A549 cells treated with HL was observed through the activation N-SMase. (b) Sphingomyelin in A549 cells after the treatment with HL decreased. (c) Anti-invasive effects of HL for A549 cells were obtained through the inhibition of 
Citation: Ichihara H, Komizu Y, Ueoka R, Matsumoto Y (2015) Inhibitory Effects of Hybrid Liposomes on the Growth of Non-small Cell Lung Carcinoma Cells and Anti-invasive Activity by Ceramide Generation without any Drugs. J Carcinog Mutagen 6: 230. doi: $10.4172 / 2157-2518.1000230$

Page 5 of 5

MT1-MMP/MMP14. (d) Inhibitory effects of HL on migration of A549 cells was obtained using scratch wound assay. The results in this study could be advantageous in chemotherapy for patients with NSCLC in clinical applications.

\section{Acknowledgments}

We thank Yumi Matsumoto for technical assistance. This work was supported in part by a Grant-in-Aid for Science Research from the Ministry of Education, Science, and Culture of Japan (Nos. 25289299 and 25420843).

\section{References}

1. Liang Y, Wakelee HA (2013) Adjuvant chemotherapy of completely resected early stage non-small cell lung cancer (NSCLC). Transl Lung Cancer Res 2: 403-410.

2. Wang J, Shen Q, Shi Q, Yu B, Wang X, et al. (2014) Detection of ALK protein expression in lung squamous cell carcinomas by immunohistochemistry. J Exp Clin Cancer Res 33: 109.

3. Cai S, Ye Z, Wang X, Pan Y, Weng Y, et al. (2015) Overexpression of $\mathrm{P} 21$-activated kinase 4 is associated with poor prognosis in non-small cell lung cancer and promotes migration and invasion. J Exp Clin Cancer Res 34: 48.

4. Zhang B, Zhang H, Shen G (2015) Metastasis-associated protein 2 (MTA2) promotes the metastasis of non-small-cell lung cancer through the inhibition of the cell adhesion molecule Ep-CAM and E-cadherin. Jpn J Clin Oncol .

5. Ganti AK, Huang CH, Klein MA, Keefe S, Kelley MJ (2011) Lung cancer management in 2010. Oncology (Williston Park) 25: 64-73.

6. Solomon B, Varella-Garcia M, Camidge DR (2009) ALK gene rearrangements: a new therapeutic target in a molecularly defined subset of non-small cell lung cancer. J Thorac Oncol 4: 1450-1454.

7. Lo FY, Tan YH, Cheng HC, Salgia R, Wang YC (2011) An E3 ubiquitin ligase: $\mathrm{c}-\mathrm{Cbl}$ : a new therapeutic target of lung cancer. Cancer 117: 5344-5350.

8. Sunaga N, Kaira K, Imai H, Shimizu K, Nakano T, et al. (2013) Oncogenic KRAS-induced epiregulin overexpression contributes to aggressive phenotype and is a promising therapeutic target in non-smallcell lung cancer. Oncogene 32: 4034-4042.

9. Douillard JY, Pirker R, O'Byrne KJ, Kerr KM, Störkel S, et al. (2014) Relationship between EGFR expression, EGFR mutation status, and the efficacy of chemotherapy plus cetuximab in FLEX study patients with advanced non-small-cell lung cancer. J Thorac Oncol 9: 717-724.

10. Niho S, Kunitoh H, Nokihara H, Horai T, Ichinose Y, et al. (2012) Randomized phase II study of first-line carboplatin-paclitaxel with or without bevacizumab in Japanese patients with advanced non-squamous non-small-cell lung cancer. Lung Cancer 76: 362-367.

11. Camidge DR, Bang YJ, Kwak EL, Iafrate AJ, Varella-Garcia M, et al. (2012) Activity and safety of crizotinib in patients with ALK-positive non-small-cell lung cancer: updated results from a phase 1 study. Lancet Oncol 13: 1011-1019.

12. Ueoka R, Matsumoto Y, Moss RA, Swarup S, Sugii A, et al. (1988) Membrane matrix for hydrolysis of amino acid esters with marked enantioselectivity. J Am Chem Soc 110: 1588-1595.

13. Matsumoto Y, Kato T, Iseki S, Suzuki H, Nakano K, et al. (1999) Remarkably enhanced inhibitory effects of hybrid liposomes on the growth of specific tumor cells. Bioorg Med Chem Lett 9: 1937-1940.

14. Nakano K, Iwamoto Y, Takata W, Matsumoto Y, Ueoka R (2002) Specific accumulation and growth inhibitory effects of hybrid liposomes to hepatoma cells in vitro. Bioorg Med Chem Lett 12: 3251-3254.

15. Matsumoto Y, Iwamoto Y, Matsushita T, Ueoka R (2005) Novel mechanism of hybrid liposomes-induced apoptosis in human tumor cells. Int J Cancer 115: 377-382.
16. Nagami H, Matsumoto Y, Ueoka R (2006) Induction of apoptosis by hybrid liposomes for human breast tumor cells along with activation of caspases. Biol Pharm Bull 29: 380-381.

17. Towata T, Komizu Y, Suzu S, Matsumoto Y, Ueoka R, et al. (2010) Hybrid liposomes inhibit the growth of primary effusion lymphoma in vitro and in vivo. Leuk Res 34: 906-911.

18. Kitajima H, Komizu Y, Ichihara H, Goto K, Ueoka R (2013) Hybrid liposomes inhibit tumor growth and lung metastasis of murine osteosarcoma cells. Cancer Med 2: 267-276.

19. Nagami H, Matsumoto Y, Ueoka R (2006) Chemotherapy with hybrid liposomes for lymphoma without drugs in vivo. Int J Pharm 315: 167-172.

20. Ichihara H, Ueno J, Umebayashi M, Matsumoto Y, Ueoka R (2011) Chemotherapy with hybrid liposomes for acute lymphatic leukemia leading to apoptosis in vivo. Int J Pharm 406: 173-178.

21. Ichihara H, Hino M, Umebayashi M, Matsumoto Y, Ueoka R (2012) Intravenous injection of hybrid liposomes suppresses the liver metastases in xenograft mouse models of colorectal cancer in vivo. Eur J Med Chem 57: $143-148$

22. Ueoka R, Matsumoto Y, Ichihara H, Kiyokawa T (2002) Chemotherapy with hybrid liposomes composed of dimyristoylphosphatidylcholine and polyoxyethylenealkyl ether without drugs. In: Marten MR, Park TH, Nagamune T (eds.) Biological Systems Engineering (ACS Symposium Series), American Chemical Society, Washington, DC, pp. 177-189.

23. Ichihara H, Nagami H, Kiyokawa T, Matsumoto Y, Ueoka R (2008) Chemotherapy using hybrid liposomes along with induction of apoptosis. Anticancer Res 28: 1187-1195.

24. Ueoka R, Matsumoto Y, Goto K, Ichihara H, Komizu Y (2011) Membrane targeted chemotherapy with hybrid liposomes for tumor cells leading to apoptosis. Curr Pharm Des 17: 1709-1719.

25. Yukihara M, Komizu Y, Tanoue O, Matsushita T, Matsumoto Y, et al. (2010) [Specific accumulation and antitumor effects of hybrid liposomes on the growth of lung tumor cells]. Yakugaku Zasshi 130: 1581-1587.

26. Komizu Y, Yukihara M, Matsumoto Y, Ueoka R (2014) Cell cycle arrest by hybrid liposomes for human lung carcinoma cells. J Carcinog Mutagen 5: 1.

27. Cao K, Tanaka K, Komizu Y, Tamiya-Koizumi K, Murate T, et al. (2012) Hybrid liposomes affect cellular lipid constituents and caveolae structures. Bioorg Med Chem Lett 22: 1731-1733.

28. Reynolds CP, Maurer BJ, Kolesnick RN (2004) Ceramide synthesis and metabolism as a target for cancer therapy. Cancer Lett 206: 169-180.

29. Hannun YA, Obeid LM (2011) Many ceramides. J Biol Chem 286: $27855-27862$.

30. Luberto C, Hassler DF, Signorelli P, Okamoto Y, Sawai H, et al. (2002) Inhibition of tumor necrosis factor-induced cell death in MCF7 by a novel inhibitor of neutral sphingomyelinase. J Biol Chem 277: 41128-41139.

31. Chi le NU, Tabuchi K, Nakamagoe M, Nakayama M, Nishimura B, et al. (2015) Ceramide/sphingomyelin cycle involvement in gentamicininduced cochlear hair cell death. Arch Toxicol 89: 415-421.

32. Huang SK, Lee KD, Hong K, Friend DS, Papahadjopoulos D (1992) Microscopic localization of sterically stabilized liposomes in colon carcinoma-bearing mice. Cancer Res 52: 5135-5143.

33. Dobrowsky RT, Kamibayashi C, Mumby MC, Hannun YA (1993) Ceramide activates heterotrimeric protein phosphatase 2A. J Biol Chem 268: 15523-15530.

34. Schubert KM, Scheid MP, Duronio V (2000) Ceramide inhibits protein kinase B/Akt by promoting dephosphorylation of serine 473. J Biol Chem 275: 13330-13335.

35. Enomoto A, Murakami H, Asai N, Morone N, Watanabe T, et al. (2005) Akt/PKB regulates actin organization and cell motility via Girdin/APE. Dev Cell 9: 389-402. 